\title{
BUSINESS MODEL CANVAS AND SUSTAINABLE PRODUCT-SERVICE SYSTEM DESIGN: PROPOSAL FOR A CONVERGENT APPROACH FOR DESIGNING SUSTAINABLE AND INNOVATIVE BUSINESS MODELS
}

CANVAS DEMODELO DENEGÓCIO EDESIGN DE SISTEMAS PRODUTO-SERVICO SUSTENTÁVEIS: PROPOSTA PARA UMA ABORDAGEM CONVERGENTE PARA O DESIGN DE MODELOS DE NEGOCIO SUSTENTAVEIS E INOVADORES

\section{Cláudio Pereira de Sampaio, Dr. (UEL) Suzana Barreto Martins, Dra. (UEL) \\ Palavras Chave \\ Design de sistemas produto-serviço; Design de modelos de negócio; Projeto de pesquisa e desenvolvimento.}

\section{Key Words}

Product-service system design; Business model design; Research \& development project.

\section{RESUMO}

Este artigo apresenta os resultados de uma pesquisa sobre a aplicabilidade do design de sistemas produto-serviço sustentáveis (S.PSS) e do design de modelos de negócio, adotando-se o Canvas de Modelo de Negócio como ferramenta principal. Este recurso é parte essencial de uma metodologia integrada e modular para a pesquisa e desenvolvimento (P\&D) que foi desenvolvida para apoiar o desenvolvimento de novos materiais, produtos e modelos de negócio a partir de resíduos sólidos, mas que também é útil em outros projetos focados em inovação sustentável. A metodologia de pesquisa utilizada incluiu, além da revisão crítica de literatura, a construção de um modelo metodológico, o qual inclui fichas-síntese para cada ferramenta nele incorporada. Os resultados apontaram que é possível combinar sustentabilidade e negócios em um método compreensível e viável para melhorar a qualidade de projetos de P\&D em resíduos sólidos, e de forma mais sistêmica.

\section{ABSTRACT}

This paper presents the results of a research on the applicability of the sustainable product-service system design (S.PSS) and business model design, adopting Business Model Canvas as a main tool. This resource is an essential part of an integrated and modular methodology for research and development (R\&D) that was designed to support the development of new materials, products and business models from solid waste, but also useful in other projects focused in sustainable innovation. The research methodology included, beyond critical literature review, the construction of the methodological model, including one-page briefs for each tool incorporated in the model. The results pointed out that is possible to combine sustainability and business in a comprehensive and feasible method to improve the quality of R\&D projects on solid waste, in a more systemic way. 


\section{INTRODUCTION}

The study here presented is part of a doctoral research developed in the period of 2013-2017, in which we investigated the problem of synthetic textile waste produced by Brazilian garment companies, and how design could contribute to solve it. We found the answer in the form of an interdisciplinary approach that combines different knowledge areas as design, chemistry, materials engineering and business that could convert an environmental passive (the solid waste) in value innovation, in the form of new materials, products and business models. This approach was then materialised as an integrated methodology for R\&D called FLOWS Model (SAMPAIO et al, 2015, $2016,2017)$, in the module of Process (Figure 1).

Figure 01: The Process module of FLOWS Model.

processo de P\&D

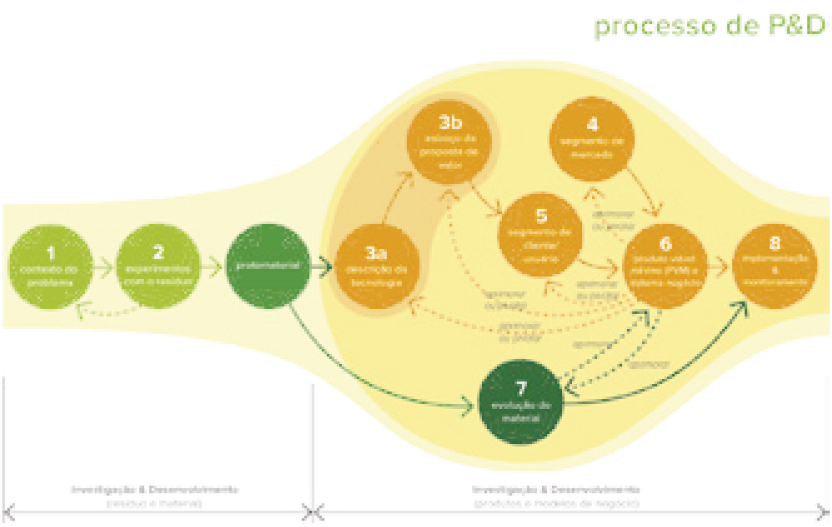

Source: Elaborated by the author (2017).

Specifically, in this paper we explore how it is possible to develop business models from solid waste that can be, at the same time, environmental and social sustainable and value-centered for the companies and consumers. For this we combined two main approaches, sustainable product-service system (S.PSS) design and business model design, using Business Model Canvas as a convergent tool that made possible to integrate the nine main business components with sustainability principles and methods. The result is a comprehensive and feasible structure that can help the R\&D team to develop a complete innovation project, from the solid waste problem understanding to the implementation of final solutions.

\section{METHODOLOGY}

This study required an extensive work to identify concepts, foundations, principles, methods and tools for each of the issues covered by the research; this was made possible by using the critical literature review, mainly based on scientific papers, books and reports, and complemented by secondary sources like business literature, organizations and respected authors websites and blogs, among others.

As a result, different designs for the methodological model were conceived by the author and discussed with his tutors, but here we present only the final structure, in which the Business Model Canvas was integrated. The methodological structure for the R\&D process here proposed was partially tested with different design student teams, using quasi-experiment with two sample and two control groups as a main method and, in addition, with other twelve groups. These tests were described in detail in another paper (SAMPAIO et al, 2017), so the focus of this paper is to explore the convergence between the S.PSS design and business model design, that were not the aim of that paper.

\section{THEORETICAL FOUNDATIONS}

\subsection{Design and value innovation}

Design is a central activity to solve problems and explore opportunities, and in this study, was considered in terms of two elements: as a way of how designers think when face a problem (design thinking), and as a practical process to understand it and solve it (design process). Empathy, applied creativity, prototyping and test are the foundations of this knowledge area, which aims to deliver, at the end of the process, benefits, here called values. As proposed by Brown (2010), these values can be for the user/consumer (functional or emotional), for some organization/company (process innovation), but also for the society (social or cultural value) or even for the planet (environmental value).

As proposed by Dorst (2010, apud Sampaio et al, 2014), value is the desired result to be achieved when we deal with "ill-defined problems", by using an approach called by him "abductive reasoning"; this differs from other areas like natural sciences, in which the aim is to obtain a valid and verifiable answer at the end of the process. Thus, value - and value innovation, for instance - is a central concept that connect design, sustainability and business models in the methodological model here proposed.

\subsection{Sustainable product-service system (S.PSS) design}

The design of sustainable product-service systems (S.PSS) represents a more sustainable strategy to reduce the environmental and social impacts, if compared to other ways like eco-design and eco-redesign of products, or cleaner production and end-of-pipe approaches. This can occur because S.PSS aim not only to develop cleaner 
products and processes, but to dematerialize the production and consumption systems, by combining the reduction of resources needed in a system with a focus on the final benefits delivered to the consumers (VEZZOLI, KOHTALA, SHRINIVASAN, 2014).

One of the most significant challenges when designing a S.PSS include the definition, articulation, involvement and management of the different actors in the system, each with its own issues, interests and levels of competence on sustainability matters. Environmental aspects, for instance, demands from the innovation team a focus on the entire life-cycle of the system needed to deliver value for the user/consumer, and not only in the products. This approach, called life-cycle design, includes a set of principles, strategies, guidelines, methods and tools.

As a result, the design of S.PSS can be developed by using a lot of methodological resources, among which the following were integrated in the FLOWS Model here proposed, according to each strategic phase. In the FLOWS Model structure, the S.PSS methods and tools (VEZZOLI, KOHTALA, SHRINIVASAN, 2014) were incorporated in the phase 6 (Minimum Viable Product and System-Business), in the following sub-phases, considering their specific guiding questions (Table 1):
Each tool is briefly described as it follows:

- System Map is a simplified visual-graphic representation of the system, including the actors and their forms of interaction (work, financial, material, knowledge) needed to make the system work.

- Stakeholders Matrix is a matrix that make possible to identify the motivations and gains expected by each of the actors involved in the system/business model. These motivations are determinant for the subsequent level of involvement in the system;

- Customer Journey is a tool to identify all the touchpoints between the user/customer and the product/service system offered by a company, and the user/customer experience along that;

- Prototype include a wide typology of resources (mockup, model, prototypes), both physical and digital, that make possible to simulate the use/consumption of the product and/or service. The level of detail can vary depending on the phase of the project and the goal defined, but in general prototypes are used to test ideas and learn more about the user/customer when interacting with them, and thus refining the design idea;

- Storyboard/Storyspot are visual-graphic tools that help the R\&D team and stakeholders understand the

Table 01: Integration of S.PSS tools in the Phase 6 of the FLOWS Process Model.

\begin{tabular}{|c|c|c|}
\hline $\begin{array}{c}\text { GUIDING } \\
\text { QUESTION }\end{array}$ & SUB-PHASE & METHOD/TOOL \\
\hline $\begin{array}{c}\text { How can I develop the business } \\
\text { systems in which the materials and } \\
\text { products will be inserted? }\end{array}$ & System \& Business & $\begin{array}{l}\text { - System Map } \\
\text { - Stakeholders matrix } \\
\text { - Customer Journey } \\
\text { - Prototype } \\
\text { - Storyboard/ Storyspot }\end{array}$ \\
\hline $\begin{array}{l}\text { How can I include the socioenviron- } \\
\text { mental aspects of sustainability when } \\
\text { developing the products and systems? }\end{array}$ & Socio-environmental aspects & $\begin{array}{l}\text { - Sustainability Drivers Checklist } \\
\text { - Sustainability Simplified } \\
\text { Benchmarking } \\
\text { - Socio-environmental SWOT } \\
\text { - Socio-environmental Value Curve } \\
\text { - SDO Checklist } \\
\text { - System Map } \\
\text { - Screening Life Cycle Assessment (LCA) }\end{array}$ \\
\hline
\end{tabular}


"story" behind the value proposition, from the problem/opportunity to the final solution, by using frames and short descriptions of each of the main scenes. It can be done using various techniques including drawings, photos and even short animated videos. Storyspot is a variation of Storyboard, but puts the entire story in a single image, that is complemented with short text indications of specific aspects or benefits of the system;

- Sustainability Drivers Checklist is a tool useful to identify and verify the priority of sustainability drivers both internal and external to a business model, in terms of three categories: socio-ethical, environmental and economic. It is complemented by a definition of what drivers will be prioritised when designing a new system/business model. This tool was part of the D4S Methodology (UNEP, 2012);

- Sustainable Design-Orienting (SDO) is a qualitative tool based on a checklist, like the previous tool, that allows the R\&D team to assess the sustainability level of a given system and others in terms of socio-ethical, environmental and economic aspects. It more complete than the Drivers, and in its software version it is possible to define different weights (Set Priority) for each aspect, and visualize the comparison results in a "visual radar", thus simplifying the communication between the R\&D team and stakeholders;

- Sustainability Simplified Benchmarking is a one-page that allows to compare the sustainability performance of a proposed system/business model compared to its competitors. Using this tool implies in the definition of a "sustainability best-practice" company that will be used as reference (benchmark) in the comparison. There is also an extended version of this tool, and both integrate, like the Sustainability Drivers, the D4S Methodology;

- Socio-environmental SWOT is a variation of the traditional and well-known SWOT Analysis, but adapted to identify and assess the strengths, weaknesses, threats and opportunities related to social and environmental aspects of a system/business model. It is also useful to analyse these aspects in the potential or real competitors, being a strategic tool to build a sustainability strategy and positioning for the business model;

- Socio-environmental Value Curve, like the previous tool, is an adaptation of the Value Curve proposed by Kim and Mauborgne (2011) for helping companies to build unique positioning in the market based on value attributes. Here, these attributes include social and environmental values, that must be different from the competitors, and they result in a unique curve for the proposed business model;

- Screening Life Cycle Assessment (LCA) is a quantitative tool (generally as a software) used to measure the environmental impacts of products, processes and services life cycle, according to specific categories (e.g. air pollution, soil depletion, acidification, carcinogenics and others). Screening LCA is a simplified version of the LCA, but even in this case is much more complex to be used than the qualitative tools previously presented, because demands specific knowledge and resources to be appropriately applied.

Each of these S.PSS methods and tools can be chosen by the R\&D team depending on the availability of expertise, time, amount of team members, or another variable involved in the project. The integration between the sustainable system subjects and the business ones is made possible by using another strategic tool, the Business Model Canvas, as seen below.

\subsection{Business model design: Business Model Canvas and Value Proposition Canvas}

Osterwalder (2011, p. 14) explains that business model is a model that "describes the way an organization create, deliver and capture value". Thus, by using simplicity and visuality as guiding principles, he developed a visual representation of a typical business structure, explaining its most relevant parts as well as its integration to deliver a specific value for a group of customers. This model, called Business Model Canvas (BMC, Figure 2), is compound by nine parts: Customer Segment, Value Proposition, Channels, Customer Relationship, Key Resources, Key Activities, Key Partners, Revenue Streams and Cost Structure.

Figure 2: Business Model Canvas.

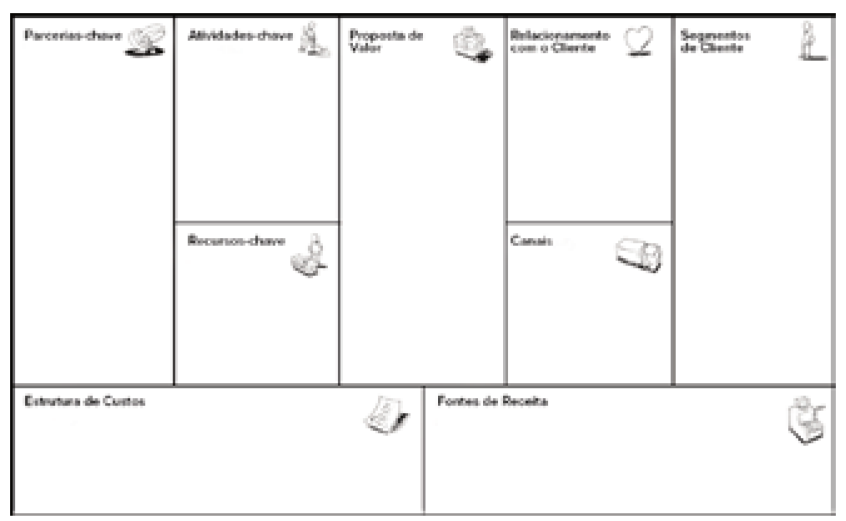

Source: Osterwalder, 2010. 
This canvas can be used together with another tool, the Value Proposition Canvas (OSTERWALDER, 2014), that emphasize two essential parts of the BMC: The Customer Segment and the Value Proposition (Figure 3). The Value Proposition Canvas is organized in two main parts: The Customer Profile and the Value Map. The first include:

- Customer Tasks: The activities the customer is trying to perform in his life, be they functional, emotional or social, as a buyer, cocreator or giver;

- Gains: What benefits the customer is trying to achieve when performing the tasks;

- Pains: The problems the customer is trying to avoid when performing the tasks, like delays, lack of quality or additional effort.

Figure 3: Value Proposition, composed of two parts, the Valeu Proposition Map (left) and Costumer Profile (right).

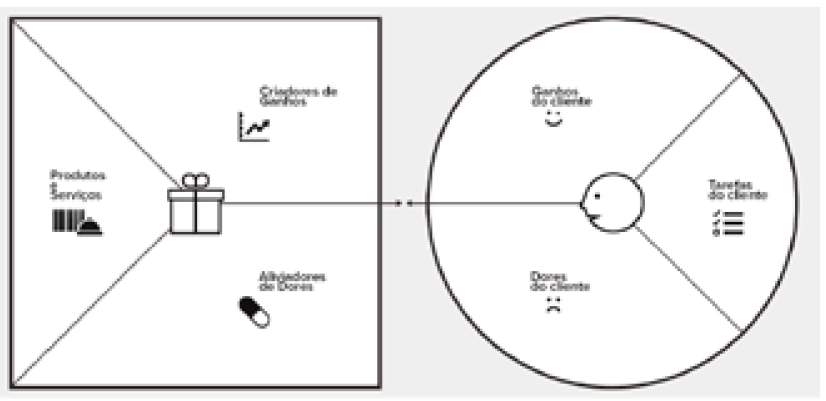

Source: Osterwalder, 2011.

\section{RESULTS}

The integration between the Business Model Canvas and the P\&D Process of FLOWS Model was designed considering the phases 3 a to 8 , as shown in the figure 4. Specifically, in the phase 6 , the integration between the BMC and the S.PSS methods and tools can be described as seen in the Table 1.

Considering this structure, it can be observed and discussed some aspects, as it follows:

- In general, there is a good distribution of tools in two main groups, one for designing the system/business model and other for evaluation and analysis of the proposals;

- All the BMC parts are contemplated with S.PSS tools, except the Cost Structure. This is the only gap to be filled in this integration;

- System Map is one of the most important tools in this integration, because allows the R\&D team to build up and visualize the entire system, including the actors and their forms of interaction. So, it must be used with the BMC since the beginning of the project;
Figure 4: Integration between the Business Model Canvas and the phases $3 a$ to 8 of the Process.

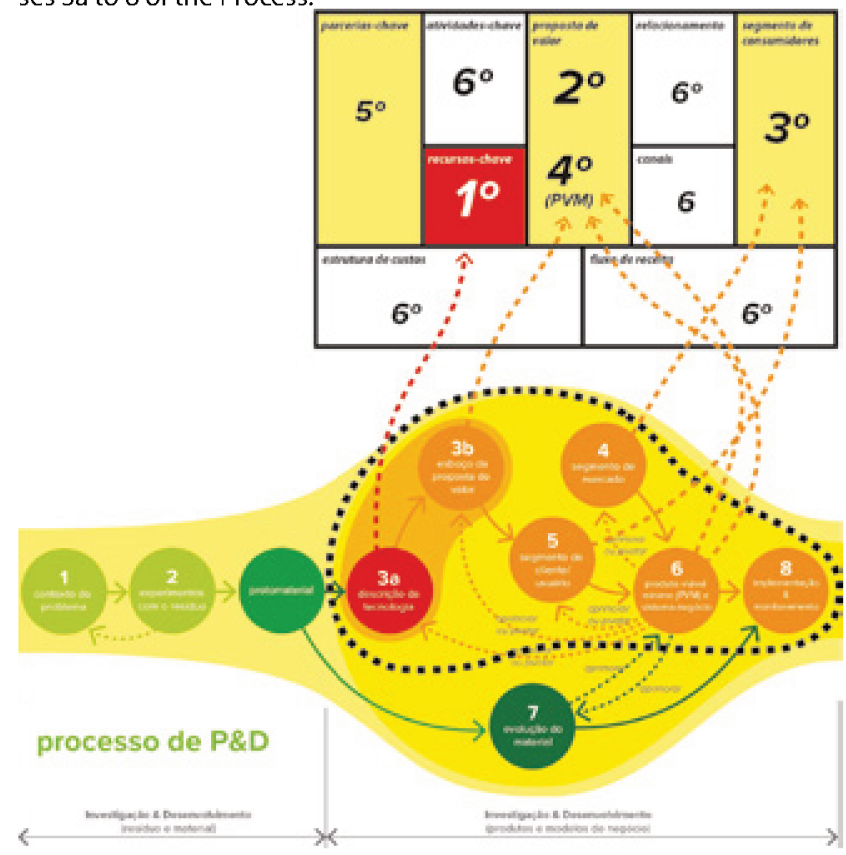

Source: Elaborated by the author.

- Also, Storyboard/Storyspot and Customer Journey are tools useful to better design the interaction between the user/customer and the system, but with different emphasis: By using storytelling, the first allows the R\&D team and stakeholders to better understand the "big picture" behind the value proposition, from the problem definition to the final solution and its benefits (gains or pain reliefs, as in the Value Proposition Canvas); the second, for instance, serve to map and detail the elements (touchpoints) with which the user/customer comes into contact when using the system; Stoyboard/Storyspot also function as a prototype tool, because can used to obtain feedback by the users/consumers and stakeholders;

- All these concept and prototype tools are relatively easy and simple to use by the R\&D team, especially that based on visual resources, like System Map and Storyboard/Storyspot, because they simplify the complexity of the system to make it comprehensive by the people, in the same logic of Business Model Canvas;

- In relation to prototypes, depending on the type used and its level of detail (mockup, model, product prototype, environment prototype, system prototype, experience prototype) all the BMC parts can be tested; It is possible to prototype and test virtually any element of the system/business model, even the cost structure, so it is one of the most embracing and important tools in this integration proposal; 
- The evaluation and analysis of the social and environmental sustainability issues of the proposed system/ business model is incorporated in this structure mainly using qualitative tools, to identify and define the most relevant aspects that affect the sustainability in the system. They include: checklists (Sustainability Drivers and Value Curve), comparative performance studies (Benchmarking), matrices for internal and external influencers (SWOT) and stakeholder's motivations (Stakeholders Matrix). All these evaluation and analysis tools can be used both for the proposed system and for competitors, if necessary;

- Additionally, it is possible to quantify the impacts of the system using a simplified version of the Life Cycle Assessment (LCA), the Screening LCA, using specific software like Simapro, Gabi, Humberto or other.
However, the use of this tool is more complex than the qualitative ones, and is recommended only if enough technical knowledge, time and resources are available;

- In terms of complexity, some tools like Sustainability Drivers Checklist, Socio-environmental SWOT and Socio-environmental Value Curve are easier to apply than others, since enough information be available to feed the assessment; Moreover, they also rely on visuality to make the result of the assessment understandable for the R\&D team and stakeholders;

- The economic-financial aspects of the system/business model are the less considered in this integrative proposal and shows a lack for specific tools that must be searched in other knowledge areas. This is an essential aspect of the Business Model Canvas, but not well supplied by the S.PSS tools.

Table 2. Integrating the S.PSS tools in the Business Model Canvas structure. Source: elaborated by the authors.

\begin{tabular}{|c|c|c|c|c|c|c|c|c|c|c|}
\hline & BAC BIAT & $\begin{array}{l}\text { 를 } \\
\text { 롤 }\end{array}$ & 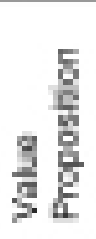 & $\frac{E}{E}$ & 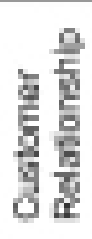 & $\begin{array}{r}\frac{1}{2} \\
+8\end{array}$ & $\begin{array}{r}9 \\
39\end{array}$ & $\frac{1}{2}$ & $\begin{array}{l}9 \mathrm{y} \\
8 \mathrm{~g} \\
\mathrm{8}\end{array}$ & 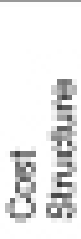 \\
\hline \multirow{4}{*}{$\begin{array}{l}\mathrm{R} \\
\mathrm{E} \\
\mathrm{E} \\
\mathrm{E} \\
\mathrm{E} \\
\mathrm{E}\end{array}$} & Bункп Мнр & $\mathrm{X}$ & X & A & A & $\mathrm{H}$ & $\mathrm{A}$ & $\mathrm{X}$ & $\mathrm{A}$ & $=$ \\
\hline & Aubms Itwmy & $\mathbf{H}$ & $x_{1}$ & $\boldsymbol{H}$ & 4 & $\mathrm{H}$ & A & $\mathrm{n}$ & 4 & - \\
\hline & 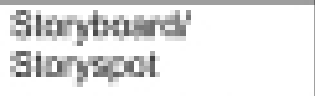 & X & 4 & $y$ & $x$ & $\mathrm{H}$ & $\mathbf{A}$ & 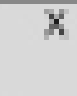 & $\mathrm{x}$ & - \\
\hline & 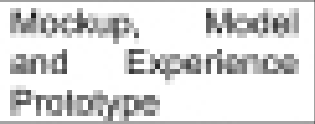 & H & 4 & $y$ & $x$ & H & H & 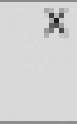 & 4 & 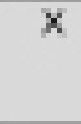 \\
\hline \multirow{7}{*}{ 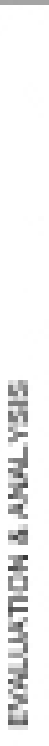 } & 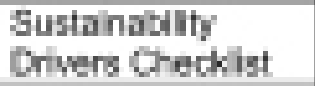 & $\mathrm{X}$ & $x$ & $\mathrm{Y}$ & $\mathrm{X}$ & $\mathrm{H}$ & A & K & - & in \\
\hline & 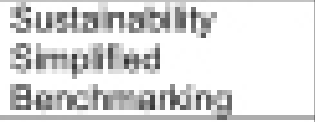 & $=$ & A & $\mathrm{x}$ & $=$ & $\mathrm{x}$ & A & $x$ & $=$ & $=$ \\
\hline & 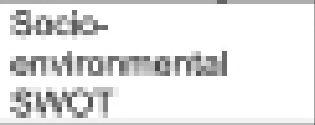 & $\mathbf{X}$ & $\mathrm{x}$ & $\mathrm{X}$ & $\mathrm{x}$ & $\mathrm{H}$ & $\mathrm{X}$ & 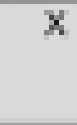 & - & - \\
\hline & 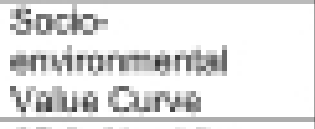 & $\mathrm{H}$ & A & H & I & $\mathrm{x}$ & A & $\mathrm{h}$ & $=$ & - \\
\hline & gDI Ehrotat & $=$ & $x_{1}$ & $\mathrm{x}$ & $\mathrm{A}$ & $\mathrm{h}$ & in & - & $=$ & $=$ \\
\hline & $\begin{array}{l}\text { Shaymothm } \\
\text { malis }\end{array}$ & $\mathrm{H}$ & - & - & - & - & A & $x$ & - & $=$ \\
\hline & 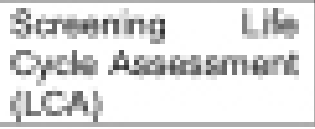 & - & 4 & $=$ & - & $\mathrm{H}$ & $\mathrm{H}$ & - & - & - \\
\hline
\end{tabular}

Source: elaborated by the author. 
In short, and based on the previous structure, we can affirm that is possible to integrate social and environmental sustainability issues when developing a business model; the integration of S.PSS tools in the existent BMC structure showed to be a viable and comprehensive strategy by means of which this can be made possible.

\section{CONCLUSIONS}

As shown in this paper, the integration of social and environmental sustainability in the business models is possible when considering sustainability as a value, because this is a central concept that integrates these two areas. Value is also a central concept for design, is its reason for being, because design always aims to produce benefits for someone, be for people, organizations or the planet. In this context, in this paper we proposed that the Business Model Canvas functionality can be enlarged by including sustainability values in the value proposition, and that this is possible by including the use of S.PSS tools in each of the BMC parts. This can help to ensure greater concern about sustainability when designing a business model, so this proposal is a working progress, and we strongly believe that can now be improved by additional contributions by other researchers in this issue.

\section{ACKNOWLEDGEMENTS}

This research was supported by the Conselho Nacional de Desenvolvimento Científico e Tecnológico - CNPq, and Fundação Araucária de Apoio ao Desenvolvimento Científico e Tecnológico do Estado do Paraná.

\section{REFERÊNCIAS}

BROWN, T. Design Thinking: Uma metodologia poderosa para decretar o fim das velhas ideias. São Paulo: Campus, 2010.

\section{DORST, K., Design Problems and Design} Paradoxes. Design Issues: Volume 22, Number 3 Summer 200622(3), pp.4-17. Available at: <http:// www.mitpressjournals.org/doi/pdf/10.1162/desi.2 006.22.3.4.> [Accessed dec18 2014], 2006.

KIM, C., MAUBORGNE, R. A Estratégia do Oceano Azul: como criar novos mercados e tornar a concorrência irrelevante; Rio de Janeiro: Campus, 2005.

OSTERWALDER, A. PIGNEUR, Y. Business Model Generation - Inovação em modelos de negócios: um manual para visionários, inovadores e revolucionários. Rio de Janeiro: Alta Books, 2011.
OSTERWALDER, A., PIGNEUR, Y., BERNARDA, G., SMITH, A. Value Proposition Design. Trad. Bruno Alexander, ilustrado por Trish Papadakos. Sao Paulo: RIES, E. The Lean Startup: How Today's Entrepreneurs Use Continuous Innovation to Create Radically Successful Businesses Crown Publishing, 2014.

SAMPAIO, C.P.; MARTINS, S.B.; ALMENDRA, R.A.; MOREIRA DA SILVA, F.J.C. New materials and products from synthetic textile waste: Development of a model for a design-oriented process development. Proceedings of the 2nd International Conference on Energy and Environment: bringing together Engineering and Economics, School of Engineering, Universidade do Minho, Guimarães, Portugal, 2015.

SAMPAIO, C.P.; MARTINS, S.B.; ALMENDRA, R.A.; MOREIRA DA SILVA, F.J.C. From solıd waste to value innovation: Proposal for a R\&D process based on design thınkıng, desıgn for sustaınabılıty and busıness models. In LENS/Brazil - Learning Network on Sustainability/ Brazil. 1st International Symposium on Sustainable Product Service Systems and Distributed Economy. Proceedings of the 1st SSPSS\&DE. Curitiba, Brazil: Núcleo de Design \& Sustentabilidade, Universidade Federal do Paraná. Available at <http://spssdeseminar.wix. com/1sspss-de> Accessed Aug 19, 2016.

SAMPAIO, C.P.; MARTINS, S.B.; ALMENDRA, R.A.; MOREIRA DA SILVA, F.J.C. Inovação e sustentabilidade a partir de resíduos sólidos: um modelo para o

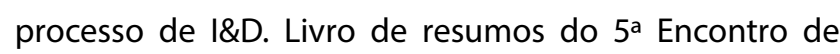
Doutoramentos em Design, UA Editora, Universidade de Aveiro, Aveiro, Portugal. Available at <http://ud16.web. ua.pt/abstracts.pdf> Accessed Aug 19, 2016.

SAMPAIO, C.P.; MARTINS, S.B.; ALMENDRA, R.A.; MOREIRA DA SILVA, F.J.C. Innovation and sustainability in materials, products and business models from solid waste: a value-based model for the R\&D process. in: E. Delfino \& C. Vezzoli, eds., Proceedings of the LeNSes Conference: Sustainable Energy for All by Design, Volume X, pp 345-353, 2016.

]AMPAIO, C.P.; MARTINS, S.B.; ALMENDRA, R.A.; MOREIRA DA SILVA, F.J.C. (2014). New materials and products from synthetic textile waste: application of abductive reasoning in a design-oriented process development, p. 511-517. In: Tradition, Transition, Trajectories: 
major or minor influences? ICDHS 2014 - 9th Conference of the International Committee for Design History and Design Studies. (São Paulo: Blucher, 2014) ISSN 2318-6968, DOI 10.5151/despro-icdhs2014-0073.

SAMPAIO, C.P.; MARTINS, S.B.; ALMENDRA, R.A.; MOREIRA DA SILVA, F.J.C. FLOWS - A Design-based Process Model for value innovation from solid waste. Proceedings of the International Symposium on Sustainable Design (ISSD). Belo Horizonte: UFMG, 2017.

VEZZOLI, C., KOHTALA, C., SRINIVASAN, A. ProductService System Design for Sustainability. LeNS Learning Networking on Sustainability. Sheffield, UK: Greenleaf Publishing, 2014. Available at http://www. lens.polimi.it/uploads/award/9781909493698_web. pdf. Accessed Jul. 20, 2016. 